Harvard. Subsidies had been granted to two missionaries in the Belgian Congo to enable them to pursue their studies of African peoples in this area. At the instance of the Commission des Sciences de l'Homme, IRSAC had subsidized the biometric researches carried out by Professor Dory under the auspices of the Institut National pour l'Étude agronomique du Congo Belge; had made a grant to the Centre pour l'Étude de l'Art Africain attached to the Musée du Congo Belge, and had given its support to the expedition to the Congo undertaken by Mlle Boone for the purpose of preparing a revised edition of Les Peuplades du Congo Belge. Professor Olbrechts also refers to the assistance given by IRSAC to Miss Mary Tew, a research fellow of the International African Institute who is making a field study. of the Bashilele of the Belgian Congo.

\title{
A Research Service for the Colonies
}

A Research Service for the British Colonies has been introduced by the Secretary of State with the object of creating a service with salary, terms of service, and standards comparable to those for research workers in the United Kingdom. Members of this service will normally work in the Colonies, but arrangements will be made whereby research workers in the Colonies may be able to work for a time at a scientific institution in the United Kingdom, and a scientist in this country to undertake research in the Colonies. All such work will count as one continuous period of pensionable service. Full details are given in the pamphlet Appointments in His Majesty's Colonial Research Service, published by the Colonial Office, London.

\section{Higher Technical Education in the Colonies}

A commitres has been set up to advise the Secretary of State for the Colonies on the development of Colonial Colleges of Arts, Science, and Technology and the expenditure of Colonial Development and Welfare funds allocated for this purpose. The committee consists of representatives of British universities, technical institutes and training colleges, of colonial education departments, and includes the Educational Adviser and Assistant Educational Adviser to the Secretary of State. Initially the committee will concern itself primarily with West Africa, where it is hoped that two new colleges, one in the Gold Coast and one in Nigeria, will be established in the near future. It will be the aim of these colleges to provide courses of Higher Technical and Commercial education as well as training courses for teachers and social welfare workers. They will also participate in adult education schemes, and will provide refresher courses and centres for the encouragement of arts and crafts.

\section{Nigerians to Study British Local Government}

TwENTY-ONE local government officials from Nigeria-fifteen Ibo and six Yorubas-are undergoing an intensive course of study in local government. After a period spent at a central training centre in Surrey they have been working in groups of three with various local authorities in England and, after a month in London and Oxford, will return to Nigeria in August.

\section{Education Plan for the Sudan}

THE Sudan Legislative Assembly recently approved a revised education plan for I949- 56 , designed to promote a more rapid expansion of education. It is proposed that by 1956 elementary and sub-grade education will be available for 40 per cent. of the population of the Northern Sudan; this will mean that the present number of elementary schools, both 